\title{
Devaluation of the National Culture in the Traditional Societies in the Period of Globalization
}

${ }^{1}$ Urunova Khamidajon, ${ }^{2}$ Saidov Abdumannon, 3 Solijonov Rasuljon

${ }^{1}$ Candidate of pedagogical sciences, Chair of social sciences Institute of Economy and Trade of Tajik State University of Commerce Republic of Tajikistan, Khujand city,

2 Professor, Doctor of philosophical sciences, chair of social sciences, Tajik Medical University, Republic of Tajikistan, Dushanbe city.

3 Doctor of philosophy, The Institute of Economy and Trade of Tajik State University of Commerce

\begin{abstract}
The article considers the issue about the problem of devaluation of the national culture in the traditional societies. The author notes that the influence of the modern globalization has several kinds, beginning from clash of cultures, fighting to modernization and development of cultures. The author emphasizes that the process of globalization is equivalent to the process of westernization as today globalization is being realized around western values. In her opinion the western culture is considered to be the dominating culture. So, she thinks that the national culture is being lost or devaluated under the influence of the dominating culture which can destruct traditions and spiritual values of eastern countries, including Tajikistan. That is why on this basis the problem of protecting national identity which is closely connected with the national mentality is being activated in many societies.
\end{abstract}




\section{HUMANITIES AND SOCIAL SCIENCE}

18 - 20 September, 2020

Key words: globalization, devaluation, traditional society, national culture, spiritual culture, spiritual values, socio-cultural changes

\section{Introduction}

Today traditional societies are experiencing cardinal changes in the material and spiritual spheres of social life. The transformational processes which are mostly rooted it the economic relationship undoubtedly are having a great impact on people's consciousness. We observe the change of the system of values and spiritual stereotypes of the people in the traditional societies which is connected with the active influence of the modern process of globalization. Today the process of transformation is being realized in many national societies, in Tajik society as well. The main task of the sociologists is to review and reanalyze the spiritual culture of the national society where the problem of contradiction of cultures is born. Here we contrast two cultures: the globalist culture which has a dominating character and the national culture which is underestimated by the members of the traditional society. In its turn the problem of cultural contradiction causes the problem of devaluation of the national culture.

In this research paper I want to show the reason of the clash of cultures and devaluation of the national culture. Besides I try to suggest some ways of saving the national culture from the threat of devaluation and disappearance, because an effective and argumentative solution of this problem helps not only to exactly identify the essence and content of the spiritual stereotypes of mentality of people, but also it promotes to fix its peculiarities and observe the process of transformation of the national mentality in new social-economic conditions.

Before analyzing the problem of devaluation of the national culture I think it is logically to characterize the globalist culture and its influence on the spiritual culture and the national mentality. For identifying the term "globalist culture" our 


\section{HUMANITIES AND SOCIAL SCIENCE}

18 - 20 September, 2020

priority is to define the term "globalization". The word "globalization" is taken from French language «global», which means total, something which covers the whole planet. As a social phenomenon globalization is a complex process which covers economic, social, political, spiritual life of people's civilization. As a scientific concept "globalization" has been widely used by scientists at the end of the last century and has several interpretations. The Russian sociologist Petrov K.P., the author of the work "The concept of social security and the theory of ruling notes that «...for a long time the process of concentration of ruling the productive power of people was going on which is called globalization. It is an objective process and does not depend on our desire. But it is possible to rule every process. Once in the ancient times the Egyptian priesthood saddled it in order to realize its plans it established specific army and all the human history is the process of globalization at all", . (Petrov K.P. 2004)

According to the confirmation of other researchers the process of globalization started in the period of Columbus when the first great geographical discoveries were made, first charter companies were opened in the XVIth century which were the organizers of the production and exchange in the world scale and the reason of signing the first international documents.

It is necessary to take the fact into consideration that beginning from 2 decades of the last century the process of interaction and interdependence of the basic spheres of person life activity in ethical societies has been fastened and became global which is considered to be the integral element of human civilization. Undoubtedly the ontological premises of the globalizational processes are rooted in the material basis of person's life and the transformational process started to happen in the second half of the XX century. In this case the scientific-technical progress has become the basic reason of increasing the

${ }^{1}$ Petrov K.P. the theory and the practice of ruling, Moscow, 2004 
18 - 20 September, 2020

productive, technological, military-technical potential of humanity and the reason of arising global problems of modern civilization.

Besides a geographical mastering of regions of the planet by Europeans and Asian people through sailing and development of culture and science of the period of Renaissance also discoveries made by great scientists in the sphere of exact sciences have promoted the process of globalization. Here we can name creating printing machine, television and its quick spreading, mechanic clocks, advancing transport means, man's fly to Space and learning it, creating world web-Internet and etc. Space-time concentration of the people of the planet has reduced the social distance. In the period of globalization the framework of social interaction has been widened and the degree of their interdependence has been increased.

Generally the process of globalization can be defined as the process of creating single world informational, economic, political, law and cultural space which interact and interrelate with each other. In the modern social science, the economic and political aspects of the process of globalization are more investigated. But the cultural aspect of this process is not investigated enough. It can be explained so that the interrelationship of global culture and national culture is happening contradictory.

\section{Clash of cultures.}

As we have mentioned before today the total globalization is an objective process and it does not depend on our wishes. It is being realized very successfully around the western values and undoubtedly causing the clash of cultures. There is an opinion in the modern social science that clash of two systems is confrontation of two worlds: old, traditional and modern. In this framework we mean not the process of acceptability of values in their historical development, but exactly confrontation which leads to political, religious, and 
18 - 20 September, 2020

cultural conflicts. Finally these two constructions are very actual and should not be disconnected.

Firstly, it should be noted that in the period of globalization the problem of clash of cultures arises in the traditional societies as globalization causes the problem of contradiction of cultures. Such confirmation is acacceptable according to the conditions of cultures (especially about their spiritual aspect) of the nations of the post-Soviet sovereign states, as Tajikistan where traditionalism and mental traits of the nation are shown distinctly. Tajik society is an example of traditional society where traditional values, customs dominate which regulate the behavior of the people there.

There we can observe a strict gender hierarchy, sustainable stereotypes which define the orientation and the system of values of the people of traditional culture. Mostly the eastern countries are considered to be traditional societies which are characterized by domination of social interests over individual and unchangeableness of traditional stereotypes. Another peculiarity of the traditional societies is that here the regulators of the social relationships are not private actions but accepted from former generations. As for the nontraditional societies it should be noted that showing individual abilities, innovations, unrepeatability, constant changes are its peculiarities. The basic determinant of the nontraditional society is developing informational society which is defined by increasing the role information, knowledge and informational technology and development of electronic democracy in social life. A member of nontraditional society believes in his individual abilities, appreciates independence and personal initiation, and the society in its turn supports them. Making a comparative analysis of the traditional and nontraditional societies it is possible to formulate the problem of clash of two worlds which arises in the period of globalization. Collectivism faces individualism, traditionalism faces innovations, and sustainability faces constant changes which promote destruction of traditions prevailing by 
18 - 20 September, 2020

centuries. That is why the problem is born and loudly can be seen more in the traditional than in the non-traditional societies. The influence of the process of globalization can be divided into several kinds: as clash, interaction or interrelationship, modernization, confrontation, conflict and others.

\section{Culture devaluation and diffusion in the period of globalization.}

The influence of the process of globalization on the spiritual culture of the traditional society has an ambivalent character. The positive impact of the globalization is shown in the other research papers written by me. Further I continue the analysis of the process of globalization and note that it can destruct many traditions and spiritual values of the eastern societies one of which is Tajikistan. Globalization in the form of westernization is destructing their traditions and values and making them as western. Today these processes are happening around the western culture and that is why the term "globalization" is used as the synonym of the term "westernization". The process of westernization introduces the traditional societies from one hand to the values which are necessary to modernize the society, but from another hand absolute contradictory one to their traditional way of thinking and behavior. The basic reason of the devaluation of the national culture is it is less attractive and economically promising than the globalist culture. This problem is mostly born among the young generation in the traditional society who are more inclined to adopt the globalist culture. It can be easily seen in their behavior, as today they want to learn English language as a globalist language; they listen to western music, wear western clothes, besides the young generation is much eager to go the western countries for study and getting a job. These and many other examples can justify the tendency of the devaluation of the national culture and domination of the globalist culture. 


\section{HUMANITIES AND SOCIAL SCIENCE}

18 - 20 September, 2020

Thus, the possessor of the national culture overestimates the globalist culture underestimating his own one. It consequently leads to the cultural diffusion. For the member of the traditional society the globalist culture is very attractive, seductive because its whole content is based on the economic relationship and interests. It seems to him promising and provokes this desire to get rich. Just this tendency attracts him to adopt a new culture making him to feel an inferiority complex before another culture. Today increasing the number of migration testifies the globalist culture being very attractive, because the members of the traditional society going out the country and being in the labor migration or in learning have to learn the language of the globalist culture and adjust under the format and style of that nation where they are. This cultural process of assimilation has a mass character today. But we cannot absolutely confirm that the mental traits of the members of the traditional societies under the pressure of the globalist culture are being transformed. Their rooted stereotypes of thinking and behavior are saved. For example, today Tajik people living in the western countries celebrate the national holiday Navruz, cook sumanak, plov, i.e. they continue keeping their collectivistic relationship between each other. But, unfortunately the collectivistic way of life and the system of relationship gradually is getting the level of nostalgia. The search of life food has made them to be separated from each other, furthermore life shows itself that today it is not beneficial to keep collectivistic binds which is characterized by the low level of poverty and low level of life. That is why the members of the traditional society voluntarily disconnect their collectivistic relationship and promote developing individualism. Collectivism is collapsing and the relationship between people is based not on relative connections, but on the pragmatism interests.

The influence of the process of globalization on the consciousness of the young people especially is being successfully realized as they are just that category of people who because of their age peculiarities and unsustainability 
18 - 20 September, 2020

of their character and outlook can easily be impacted. Young generation mostly is inclined to receive more the western culture, values and life style than to be devoted to their traditions. Young generation following the traditional norms compulsorily, but as for joining to the globalist culture they do it voluntarily. Today modern young generation tend to learn western languages, wear western clothes, listen western music and at last realize western life style because the globalist culture having introduced new "fashionable" tendencies under the title "fashion" attracts young people. At the result the national culture loses its value and attractiveness, i.e. the process of devaluation of the national culture is born.

\section{What should be done?}

The influence of the process of globalization on the national culture and the mentality of the traditional society can be seen also in other spheres of people's life. One of the strategic approaches of the state policy in our country in the period of globalization is adopting the law "About regulation of parties", the basic purpose of which is to adapt to the modernized tendencies and decrease the level of poverty. According to the law it is prohibited to have big parties which lets people to improve the family budget. Such approach on a state level gradually turns the collectivistic tendencies into individualistic system of relationship. The influence of the process of globalization on the mentality of the traditional society can be shown in the example of changing paternalism into liberalism among young generation. It should be noted that under this influence the level of upbringing, morality, shame of both man males and females. We should not forget that modern process of globalization inevitably cause the process of modernization of the society and its transformation where the survival of the national society especially its spiritual culture as the most priority imperative of saving its uniqueness firstly depends on the content of the culture. That is why following 2 principles can provide 


\section{HUMANITIES AND SOCIAL SCIENCE}

18 - 20 September, 2020

the effectiveness of the socio-cultural modernization of the traditional societies:

1) Anthroposocial conformity of the transformational processes with the parameters of the socio-cultural code of the national society, where "modernization" and "traditionalization" are considered to be the basic types of it. They interact, correct each other and can comparatively guarantee the harmony of the transformational processes in the national society.

2) The principle of socio-cultural balance which means balance between cultural and social components as the basic condition of sustainability of the society. Its parameters usually hesitate beginning from dominating traditional to the process of modernization. ${ }^{2}$ (Snegovaya, 2007)

In the opinion of the Russian sociologist Snegovaya the transformational processes in the traditional society should have a conformity with the cultural parameters which have a sustainable character here. Besides there should be a balance between the process of modernization and traditionalism in the traditional society, otherwise the threat of devaluation of the national culture is great.

It should be noted that it is necessary to emphasize that a creative adoption of the spiritual culture of the western civilization and using them taking the socio-cultural peculiarities of the traditional societies is much more useful than a passive imitation. Of course a threat of losing the national identity of the country can be the result of the influence of the globalization which has a destructive character in the socio-cultural space of Tajikistan.

Also it should be mentioned that after the collapse of the Soviet Union and national conflict in Tajikistan led to the spiritual decline which caused a socio-cultural vacuum which was filled by western values. That is in all the

${ }^{2}$ Snegovaya O.A. Globalization as a socio-cultural process. Autoabstarct of the diss. Of the candidate of philosophical sciences. - Rostov -on -Don, 2007. 
18 - 20 September, 2020

new formed states, privately in Tajikistan a new plan of keeping the cultural heritage of the nation was designed.

Among the researchers there is a wide spread confirmation that the process of globalization can absorb the national culture. In fact in the national cultures need to be similar to the western culture in order to be "heard" by other cultures and develop, as we know assimilation reduces the originality of the culture. But there is no another way as the process of globalization makes those cultures "heard" which maximally conform to the western culture. At the result nothing will be left about the uniqueness of the national culture. Though the west does not have any requirements towards the national cultures but it is successfully achieving its goals through indifference toward them. However if to demand being original and not to try to be "heard" the national society can be left interesting only in its space and be isolated from the world community. Naturally in the "park" of the ethical culture the globalist culture is intruding which can easily set its superiority over any national culture. Obviously traditionalism and modern interact with each other, in other words they are two sides of the same process. That is why for marking today globalization processes exactly and for noting that coexistence of synthesis and destruction is not an occasional case and it is impossible to avoid or cancel it, the expert use the term "glocalization",

It cannot be ignored that today the development of the society is going on as a transition from the national to the globalist culture which is naturally. The language of the globalist culture is English, moreover the national currency of the USA -dollar has become the international financial means of purchase and sale of goods. The mass Western culture is swiftly intruding into the cultural space of other nations a liberal-democratic model of society anyway is being adopted as a standard by other nations, a single informational world

${ }^{3}$ Orlov F.I. Social expenses of the globalization// Sociological investigation, 2001. - № 7. - p.13-22. 
18 - 20 September, 2020

space is made (Internet, the newest informational and communicational technology) through which the process of westernization of the spiritual culture of other nations is being. In counterweight to it such movements have been appeared as antiglobalists for whom the issue of protecting and keeping the cultural identity and its uniqueness is very demanding. In such situation we should take it easy and try to transfer the spiritual culture of the nation into the working language of the globalist culture and worthily show it to the people, only then the national culture will be saved and free of damage. In the same time it is not correct to be limited by the boundaries of the national culture, but it is necessary to find the painless way of exit to the world cultural space. As for the Tajik spiritual culture for the best presentation it can do something in the framework of permitted level.

Of course it will not be a catastrophe if the national culture of the traditional society cannot meet a wide understanding by the western societies. Finally it is a national culture and should express the peculiarities of the nation. It can and should bring up its people in the framework of the values of this nation. And

"if it is a real culture then a person will be interesting for the world as the universal culture is formed through the cultural identity of nations. ${ }^{4}$ ",

The strength of the national culture is just in the specific traits of its values as they are the unique way of understanding the world and its meaning.

\section{Conclusion}

Thus in the period of modern process of globalization the problem of clash of cultures is objective and inevitable. The national societies should use the principle of glocalization which means adaptation of the western culture and values to the local traditions of the national societies. Using this principle gives us opportunity to make a cross-cultural bridge and make a constructive

${ }^{4}$ Kosichenko A.G. National cultures in the process of globalization // http://www.orda.kz. Electronic informative analytic bulletin. - №№ 8, 9. 


\section{iachss}

\section{$4^{\text {th }}$ International Academic Conference On}

\section{HUMANITIES AND SOCIAL SCIENCE}

18 - 20 September, 2020

dialogue between the globalist and national culture. I think this is the rational decision in the period of devaluation of cultures.

Devaluation of the national culture puts a serious task before the sociologists to find the mechanism of protection and propaganda of the national culture. As the process of globalization allows the national societies to select the elements of the western culture so it is possible to make a constructive dialogue with. It goes without saying that it is very important to strengthen the national security of the independent states formed in the post-Soviet space in the Central Asia.

Thus we can come into conclusion that the problem of devaluation of the national culture cannot be stopped, it can be only slow down through propaganda of the national society. Besides if we want the national culture not to be under the threat of devaluation we should remember that the national culture should have the following character: it should be demanding necessary, competitive, and meaningful.

\section{Reference}

1. Birukova M.A. Globalization: integration and differentiation of cultures // Philosophical sciences, 2000. - № 4. - p. 33-42.

2. Gubanov N.N. Mentality: the essence, regularity of forming, development and functioning inn the society. Autoabstarct of the diss. Of the doctor of philosophy. - M., 2014.

3. Kosichenko А.Г. National cultures in the process of globalization.// http://www.orda.kz. Electronic informative -analytic bulletin. - №№ 8, 9.

4. Marx., Engels F. German ideology. - M.: Politizdat, 1983. - p. 29.

5. Mitroshenkov O.A. Culture and civilization // Person. Culture. Society. - M., 2003. - V. 2. - p. 219.

6. Saidov A.S. Nation as a subject of social action. - Minsk -Dushanbe, 1999. - 248p. 


\section{iachss}

$4^{\text {th }}$ International Academic Conference On

\section{HUMANITIES AND SOCIAL SCIENCE}

18 - 20 September, 2020

7. Snegovaya O.A. Globalization as a socio-cultural process. Autoabstarct of the diss. of the candidate of the philosophical sciences. - Rostov -on-Don, 2007.

8. Haydarov. R.J. The influence of the process of the globalization on the transformation of the Tajik society. Autoabstarct of the diss. Of the doctor of philosophy. Dushanbe, 2007.

9. Culture: The Diffusion Controversy. - N.Y., 1927.

10. Orlov F.I. Social outgoings of globalization// Sociological investigation, 2001. - № 7. - C. 13-22. 